\title{
PENGGUNAAN PELACAK NONRADIOAKTIF (Digoxigenin-DNA Probe) UNTUK MENDETEKSI PEANUT STRIPE VIRUS
}

\author{
Hasriadi Mat Akin ${ }^{1}$
}

\begin{abstract}
The use of nonradioactive probe (Digoxigenin-DNA) for detection of peanut stripe virus The objective of this experiment was to develop the nonradioactive-labeled probe to detect peanut stripe virus (PStV) in peanut leaves and seeds. Digoxigenin labeled cDNA (dig-DNA probe) was synthesized from recombinant plasmid (pHS1.23) using polymerase chain reaction (PCR). The probe containing 1.195 bp (base pair) corresponding to 3' termini, included part of NIb (nuclear inclusion body) gene, coat protein gene, and 3' untranslated region of PStV genome was used to detect the existence of PStV in peanut leaves and seeds of infected peanut plants.
\end{abstract}

Key words : peanut stripe virus, nonradioactive probe, digoxigenin

\section{PENDAHULUAN}

Penyakit bilur yang disebabkan oleh peanut stripe virus (PStV) merupakan penyakit penting dan secara ekonomi sangat merugikan dalam budidaya kacang tanah. Penyakit ini dapat menurunkan hasil kacang tanah antara 15-70\% (Saleh \& Baliadi, 1990; Wakman et al., 1989). Epidemi PStV dimulai dari biji dari tanaman induk yang terinfeksi sebagai sumber inokulum pada awal pertanaman kacang tanah selanjutnya melalui serangga vektor ditularkan ke tanaman-tanaman sehat.

PStV berbentuk batang lentur (flexious rod) dan berukuran 12 x $752 \mathrm{~nm}$. Virion terdiri atas satu utas RNA (ssRNA) dengan bobot molekul (BM) 3100 $\mathrm{kDa}$ dan protein selubung yang terdiri atas subunitsubunit protein dengan BM $31 \mathrm{kDa}$ (Demski et al., 1984). Genom PStV terdiri atas 10059 bp (nuleotida) tidak poli-A pada terminal 3' RNA. Pada ujung bagian 5' genom RNA terdapat protein (VPg) yang terikat secara kovalen pada RNA (Gunashinghe et al., 1994). Genom PStV tersebut terdiri atas satu ORF (open reading frame) yang meliputi 95\% dari total RNA. Kodon awal terletak 134-136 dan kodon stop 9768-9770 nukleotida dari ujung bagian 5'RNA PStV (Gunashinghe et al., 1994).

Metode deteksi PStV sangat diperlukan untuk kajian epideiologi penyakit bilur pada budidaya kacang tanah. Keterbatasan metode serologi yang selama ini banyak digunakan dalam virologi tumbuhan seperti: (1) reaksi silang dengan virus-virus lain, (2) reaksi positif palsu (false positive), dan (3) hanya dapat mendeteksi virion dan tidak dapat mendeteksi genom atau bagian dari genom virus. Metode deteksi virus tumbuhan yang dapat digunakan untuk mendeteksi virion dan genom virus sangat sangat diperlukan untuk menunjang pengembangan rekayasa genetika tanaman tahan virus.

Prinsip deteksi dengan hibridisasi adalah terjadinya hibridisasi antara pelacak PStV dan genom RNA-PStV. Deteksi ini mempunyai spesifisitas yang tinggi karena ketepatan deteksi didasarkan atas kesamaan runutan nukleotida antara pelacak dan genom virus yang akan dideteksi. Oleh sebab itu, pengembangan metode deteksi menggunakan pelacak cDNA perlu dilakukan untuk dapat mengatasi kelemahan metode deteksi konvesional seperti deteksi serologi.

\section{BAHAN DAN METODE}

\section{Tempat dan Waktu Penelitian}

Penelitian ini dilaksanakan di Laboratorium Biologi Molekuler, Jurusan Budidaya Pertanian, Institut Pertanian Bogor. Penelitian ini dilaksanakan dari bulan Januari sampai Agustus 1998.

\section{Sintesis Pelacak Digoksigenin DNA}

Pelacak yang digunakan terdiri atas cDNA yang dilabel dengan digoksigenin (dig-DNA). Pelacak tersebut merupakan komplementer dari genom RNA-PStV pada runutan nukleotida sebagian

\footnotetext{
${ }^{1}$ Dosen Jurusan Proteksi Tanaman, Fakultas Pertanian, Universitas Lampung
} 
gen NIb (nuclear inclusion body), gen CP (coat protein gene), dan ujung 3' untranslated region (3'UTR) yang panjangnya 1.195 bp (Gambar 1). Pelacak disintesis dengan teknik PCR dengan cetakan plasmid rekombinan (pHS1.23) yang mengandung sisipan genom PStV (Akin, 2000). Primer oligonukleotida yang digunakan adalah PST1
(5'GCATGCCCTCGCCATTGCAA3') yang komplementer dengan nukleotida ke 10003-9984 pada bagian 3' UTR dan PST4 (5'TACATAGCAGAATCAGCACT3') yang homolog dengan nukleotida 8810-8829 pada sistron nib. Prosedur pelabelan pelacak PStV dengan digoksigenin dilakukan mengikuti metode Dietzgen et al. (1998).

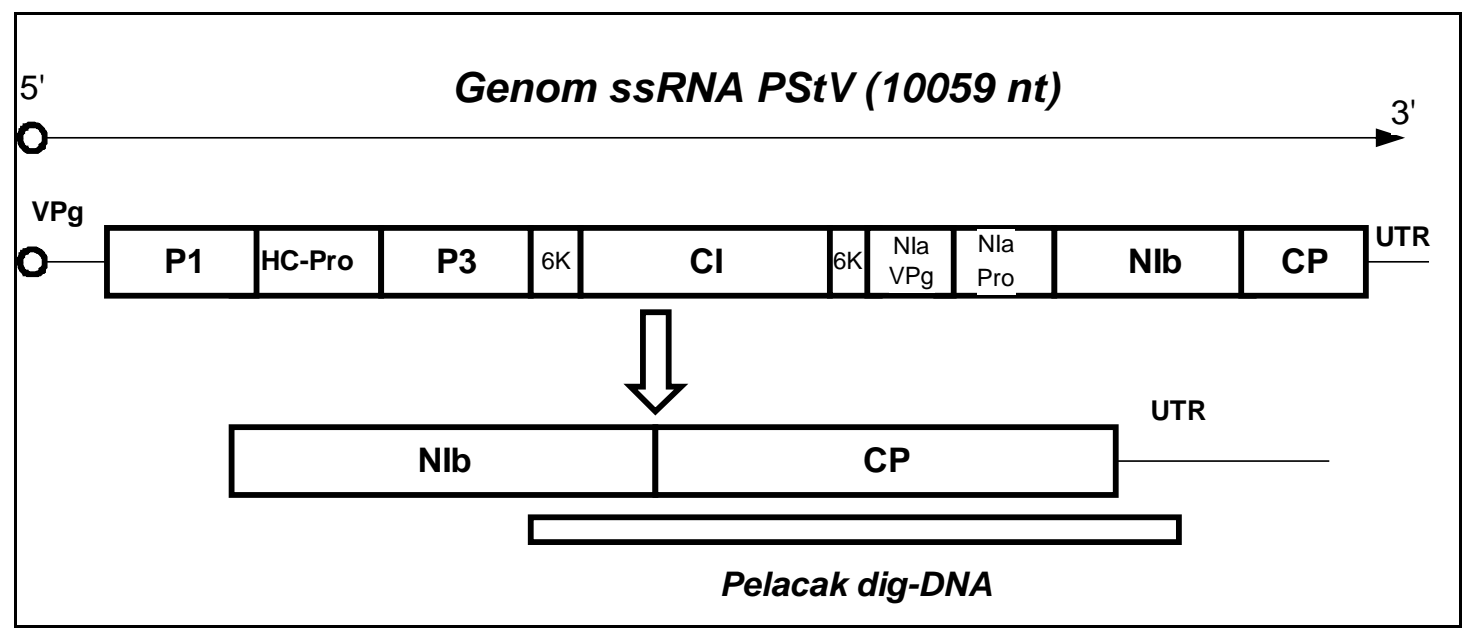

Gambar 1. Posisi hibridisasi pelacak pada genom RNA PStV untuk deteksi PStV dengan hibridisasi dot blot

\section{Deteksi PStV pada daun kacang tanah}

Contoh daun yang terinfeksi PStV (0,5 gr) dan $1,5 \mathrm{ml}$ dapar (bufer) ekstraksi (50mM natrium sitrat $\mathrm{pH}$ 8,3) digerus dengan mortar steril dan ekstraknya disentrifugasi (12.000 rpm, 5 menit) pada suhu kamar. Supernatan diencerkan menjadi $1 / 20$, 1/100, dan 1/500 dengan dapar denaturasi (12 x SSC mengandung $6 \%$ formaldehide) (20 x SSC $=3 \mathrm{M}$ $\mathrm{NaCl}, 0,3 \mathrm{M}$ natrium sitrat) dan $2 \mu$ liap-tiap contoh yang diencerkan diblot pada membran nilon.

\section{Deteksi PStV dalam Benih Kacang Tanah}

Biji kacang tanah (50 mg) digerus dalam 450 $\mu \mathrm{l}$ dapar ekstraksi (1M Tris-HCl, pH 7,6, $200 \mathrm{mM}$ LiCl, 2\% SDS, 20 mM EDTA) dan ditambah dengan $450 \mu \mathrm{l}$ fenol/kloroform. Suspensi tersebut diinkubasikan selama 5 menit pada suhu $65^{\circ} \mathrm{C}$, dan disentrifugasi $12.000 \mathrm{rpm}$, selama 10 menit. Setelah $350 \mu \mathrm{l}$ supernatannya dibuang, ke dalam endapannya ditambah lagi $450 \mu \mathrm{l}$ fenol/kloroform dan disentrifugasi, kemudian $300 \mu$ l supernatannya dibuang dan ke dalam endapannya ditambahkan $3 \mathrm{M}$ sodium asetat, $660 \mu \mathrm{l}$ etanol dan diinkubasikan 2 jam pada $-20^{\circ} \mathrm{C}$. Suspensi tersebut disentrifugasi (12.000 rpm, 20 menit, $4^{\circ} \mathrm{C}$ ) dan dikeringkan menggunakan pengering vakum dan diresuspensi dengan $500 \mu \mathrm{l}$ $\mathrm{dH}_{2} \mathrm{O}$ (1/10 dari larutan awal).

\section{Hibridisasi Pelacak}

Sebelum diblot membran nilon (Boehringer Mannhein) dibasahi dengan air bebas RNase dan diequilibrasi dalam $20 \quad \mathrm{x}$ SSC, kemudian dikeringanginkan di atas kertas saring. Setelah diblot dengan sampel yang telah disiapkan, membran tersebut diradiasi dengan UV (50 mJoule) agar RNA virus terfiksasi pada membran nilon. Selanjutnya membran nilon yang telah diperlakukan dengan UV disimpan dalam ruangan gelap.

Hibridisasi pelacak PStV dengan contoh asam nukleat (RNA-PStV) dilakukan mengikuti prosedur standar sebagaimana yang direkomendasikan oleh Boehringer Mannheim. Deteksi adanya sinyal hibridisasi dilakukan dengan menggunakan fragmen 
anti-Dig yang dikonjugasikan dengan alkalin fosfatase, dan substrat NBT (nitroblue tetrazolium), dan X-fosfat (5-bromo-4-chloro-indolylphosphate). Adanya hibridisasi menyebabkan warna biru pada membran nilon dimana ekstrak tanaman terinfeksi PStV berada.

\section{HASIL DAN PEMBAHASAN}

\section{Sintesis Pelacak cDNA (digoxigenin-DNA)}

Hasil sintesis pelacak cDNA yang dilabel dengan digoxigenin berukuran 1195 bp (Gambar 2). Pelacak DNA yang digunakan berukuran 1195 bp merupakan komplemen dari NIb (129 bp), gen CP (861 bp), dan bagian 3' UTR (205 bp).

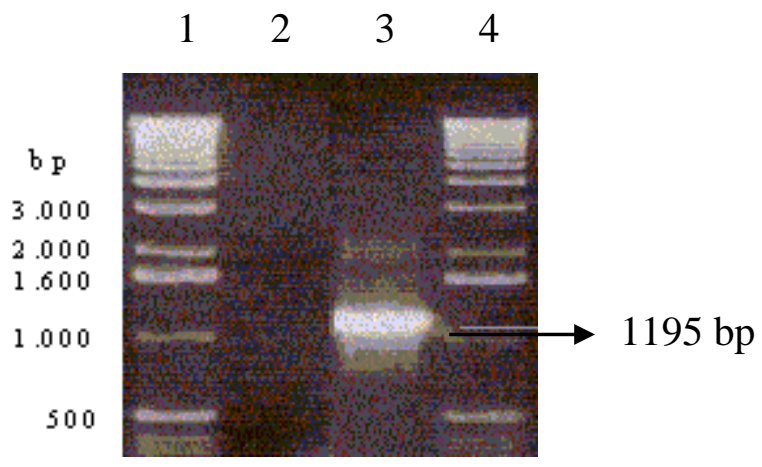

Gambar 2. Amplifikasi PCR pelacak cDNA berukuran 1195 bp. Lajur 1 dan 4: Marka 1 kb; lajur 2: kontrol (PCR tanpa templat pHS1.23); lajur 3: amplifikasi pelacak

\section{Deteksi PStV pada Daun Kacang Tanah}

Deteksi PStV dengan hibridisasi dot blot pelacak DNA yang dilabel dengan digoksigenin menunjukkan bahwa daun kacang tanah yang terinfeksi isolat PStV menghasilkan reaksi positif
(Gambar 3). Signal positif pada deteksi hibridisasi dot blot membuktikan adanya komplementasi antara pelacak dan RNA PStV. Sebaliknya reaksi negatif pada sampel yang berasal dari daun tanaman sehat menunjukkan bahwa bahwa dalam daun tersebut tidak terdapat PStV.

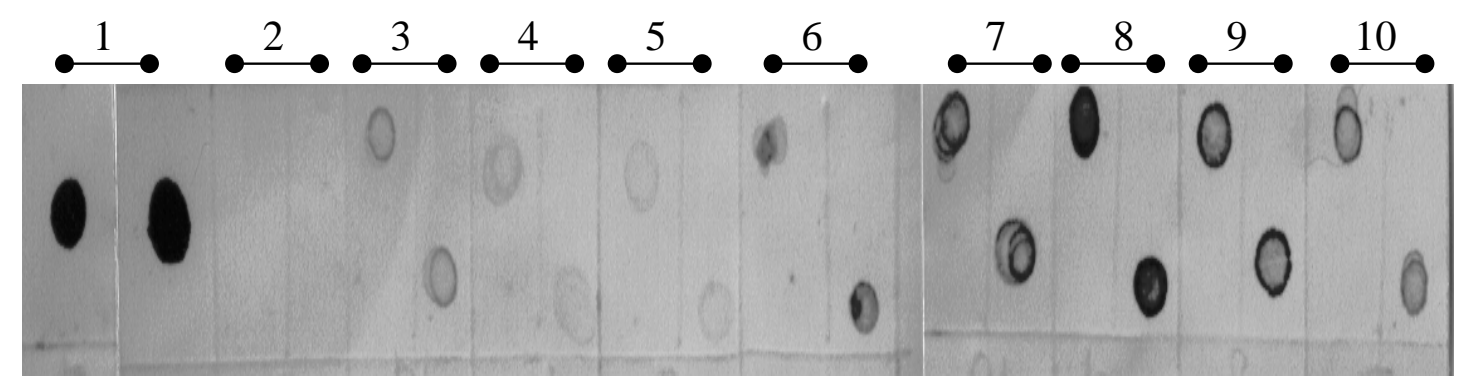

Gambar 3. Hasil deteksi PStV pada daun kacang tanah dengan teknik hibridisasi dot blot pelacak digoxigeninDNA. Lajur 1: Kontrol positif (pHS1.23); 2: Kontrol negatif (daun kacang tanah sehat); 3-10: daun kacang tanah terinfeksi PStV

Hasil percobaan pengenceran sampel ekstrak daun kacang tanah terinfeksi menunjukkan bahwa pengenceran 20 kali memberikan hasil deteksi yang lebih baik (Gambar 4). Meningkatnya pengenceran sampel lebih lanjut akan menurunkan signal hasil deteksi yang diamati dengan berkurangnya intensitas warna biru yang dapat diamati pada membran nilon tempat sampel diteteskan. Selanjutnya pada 


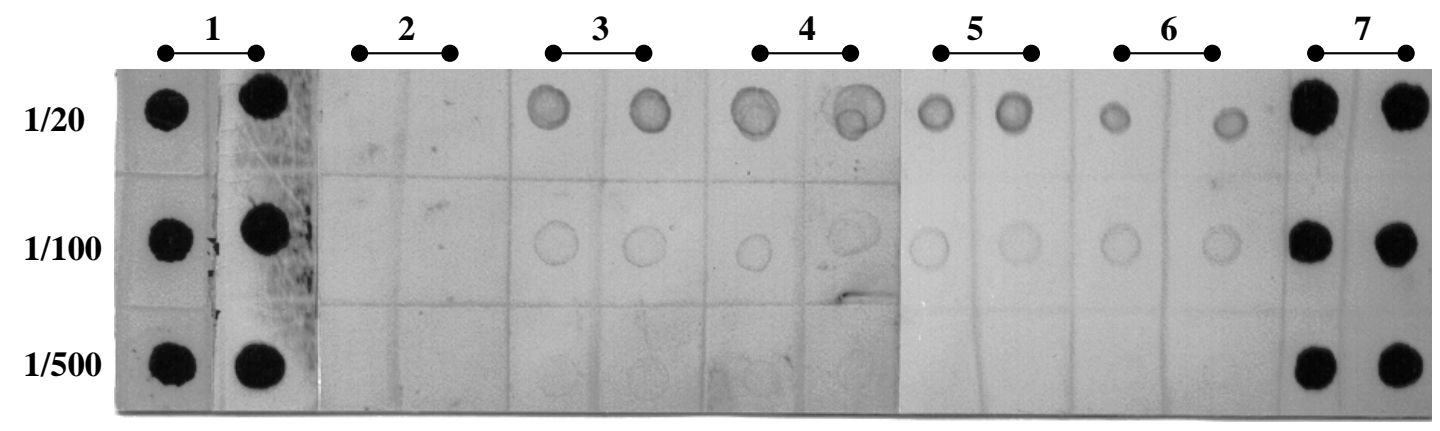

Gambar 4. Limit deteksi PStV dengan hibridisasi dot blot.

Lajur 1 dan 7: Kontrol positif (pHS1.23); 2: Kontrol negatif (daun kacang tanah sehat); 3-6: Daun kacang tanah terinfeksi PStV. Baris 1: pengenceran sampel 20 kali; 2: pengenceran sampel 100 kali; 3: pengenceran sampel 500 kali.

pengenceran sebesar 500 kali, hasil hibridisasi tidak dapat diamati.

\section{Deteksi PStV pada Biji Kacang Tanah}

Deteksi PStV menggunakan pelacak dig-DNA selanjutnya digunakan untuk deteksi PStV pada biji yang diperoleh dari tanaman induk yang terinfeksi
PStV. Hasil deteksi menunjukkan bahwa dua dari sepuluh biji terinfeksi PStV yang ditunjukkan oleh reaksi positif dengan pelacak PStV (dig-DNA) (Gambar 5). Reaksi positif menandakan adanya hibridisasi antara pelacak dig-DNA dan genom PStV yang terdapat dalam biji kacang tanah.
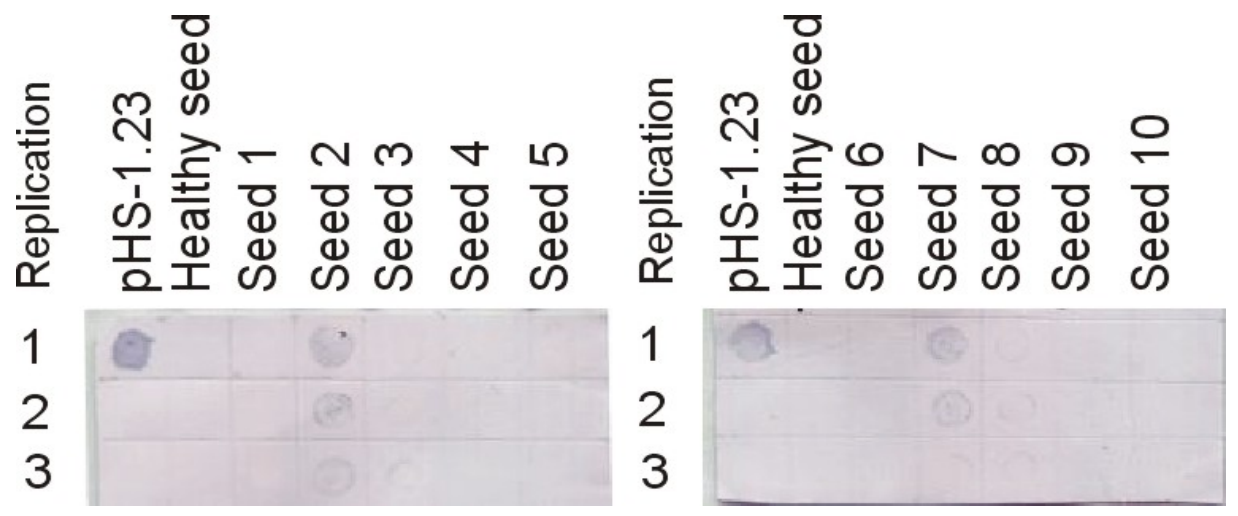

Gambar 5. Deteksi PStV pada benih yang didapatkan dari tanaman induk yang terinfeksi PStV dari lapang. Lajur 1: kontrol positif (pHS1.23); 2: kontrol negatif (benih sehat); seed 1-10: benih yang dari tanaman kacang tanah terinfeksi PStV; seed 2\&7: terinfeksi PStV.

Penelitian Saleh et al. (1991) menunjukkan penggunaan benih bebas virus (PStV) merupakan salah satu cara yang efektif untuk menekan laju epidemiologi penyakit bilur di lapang. Hasil penelitian Muhsin (1993) menunjukkan persentase penularan PStV melalui biji 0-4\%. Saleh et al. (1989) melaporkan penularan PStV melalui biji untuk kultivar Gajah 0,3\% dan kultivar Kelinci 0,6\%. Persentase penularan melalui biji juga semakin tinggi apabila tanaman kacang tanah terinfeksi oleh beberapa jenis virus (Warwick \& Demski, 1992).

Deteksi dengan hibridisasi dot blot telah berhasil digunakan untuk deteksi PStV pada biji kacang tanah yang berasal dari tanaman induk yang terinfeksi PStV. Peranan penularan PStV melalui biji dalam epidemiologi penyakit bilur telah dilaporkan oleh Saleh et al. (1991) yang melaporkan penggunaan benih bebas virus (PStV) efektif menurunkan laju 
epidemiologi penyakit bilur di lapang. Keberhasilan deteksi dengan hibridisasi dot blot ini dapat dikembangkan untuk sertifikasi benih bebas virus. Dietzgen et al. (1994) melaporkan penggunaan pelacak cRNA yang dilabel dengan digoksigenin untuk deteksi PStV dengan teknik hibridisasi dot blot menunjukkan reaksi yang peka dan spesifik dan tidak terjadi reaksi silang antara pelacak dan virus lain yang juga menginfeksi kacang tanah seperti peanut mottle virus (PeMoV).

\section{KESIMPULAN}

Dari hasil penelitian ini dapat disimpulkan bahwa pelacak DNA yang dilabel dengan digoksigenin dapat digunakan untuk deteksi PStV dalam sampel dari daun dan biji kacang tanah.

\section{SANWACANA}

Penulis mengucapkan terima kasih dan penghargaan yang sebesar-besarnya kepada Proyek URGE (University Research for Graduate Education) dan ACIAR (Australian Centre for International Agricultural Research) atas dukungan dana untuk melakukan penelitian. Ucapan terima kasih juga disampaikan kepada Dr. Ir. Sudarsono, M.Sc. dan Prof. Dr. Edi Guhardja atas segala bantuannya selama melakukan penelitian.

\section{DAFTAR PUSTAKA}

Akin, H. M. 2000. Pengklonan dan perunutan nukleotida gen selubung protein dan 3'UTR (untranslated region) peanut stripe virus. Jurnal Hama dan Penyakit Tumbuhan Tropika 1(1): 1-6.

Dietzgen, R.G., Z. Xu, \& P. Teycheney. 1994. Digoxigenin-labeled RNA probes for the detection of two potyviruses infecting peanut (Arachis hypogaea). Plant Disease 78(7): 708-711.
Dietzgen, R.G., M. Abedina, C.M. Higgins, S. Karunatratne, \& J. Vickers. 1998. Nonradiaoctive detection of transgenense in plant genomic shoutern blots. http://biochem.boehringer-mannhein.com/ biochemia/No1_99/B199 diet.htm.

Demski, J.W. \& D.V.R. Reddy, Jr., G. Sowell, \& D. Bays. 1984. Peanut stripe virus- a new seed-borne potyvirus from China infecting groundnut (Arachis hypogaea). Ann. App. Biol. 105: 495-501.

Gunashinghe, U.B., S. Flasinski, R.S. Nelson, \& B.G. Cassidy. 1994. Nucleotide sequence and genome organization of peanut stripe potyvirus. J. Gen. Virol. 75: 2519-2526.

Muhsin, M. 1993. Ekobiologi PStV dan pengembangan metode pengendalian penyakit belang kacang tanah. Risalah Hasil Penelitian Tanaman Pangan 5: 51-57.

Saleh, N, Y. Baliadi, A. Munif, S. Karsono, Riwanodja, \& Suwono, 1991. Pengendalian peanut stripe virus pada kacang tanah dengan cara kultur teknis dan insektisida. Hlm. 193-198 dalam: Risalah Hasil Penelitian Tanaman Pangan. Balittan Malang.

Saleh, N. \& Y. Baliadi. 1990. Transmission of peanut stripe virus in groundnut seed in Indonesia. Pages 333-335. in: Proceedings of third International Conference on Plant Protection in the Tropics. Gentling Highlands, Pahang, Malaysia

Saleh, N., K.J. Middleton, Y. Baliadi, N. Horn, \& D.V.R. Reddy. 1989. Research on peanut stripe virus in Indonesia. Pages 9-10 Summary Proceeding of the Second Coordinators Meeting on Peanut Stripe Virus. India, 1-4 Agustus 1989.

Wakman, W., S. Pakki, \& A. Hasanuddin. 1989. Yield loss of groundnut due to peanut stripe virus. Page 11. Summary proceeding of the second coordinators meeting on peanut stripe virus. India, 1-4 Agustus 1989.

Warwick, D.R.N. \& J.W. Demski. 1992. Factor influencing peanut stripe virus (PStV) transmission in peanut seeds. Fitopatologia-Brasileira 17(4): 389-392. 